\title{
FACTORS INFLUENCING MESOSTIGMATA MITES (Acari, Parasitiformes) IN THE ALKALINE FEN HABITATS
}

\author{
Ineta Salmane* and Voldemārs Spunģ́is ${ }^{\star \star}$ \\ * Institute of Biology, University of Latvia, Miera iela 3, Salaspils, LV-2169, LATVIA; \\ ineta.salmane@laapc.Iv \\ ** Faculty of Biology, University of Latvia, Kronvalda bulv. 4, Rīga, LV-1586, LATVIA \\ \# Corresponding author
}

Communicated by Viesturs Melecis

\begin{abstract}
Mesostigmata mite fauna was investigated in soil of one alkaline fen at Apšuciems in the Maritime Lowland in Latvia in 2009. Thirty sample plots were selected in the following way: half of them were located in Brown Bog Rush, Schoenus ferrugineus and half - in Saw-Sedge, Cladium mariscus prevailing habitat. Soil samples were collected using a soil borer. Vegetation cover was described in accordance with Braun-Blanquet classes. Mites were extracted using modified Berlese funnels. In total, more than 28 species were recorded, of them Prozercon kochi and Pergamasus vagabundus were dominant species. Mean density of Mesostigmata mites ranged from 520 to $2140 \mathrm{ind} . / \mathrm{m}^{2}$. Mite abundance and distribution between habitats depended on vegetation cover of the vascular plants, while moss cover and soil $\mathrm{pH}$ had no significant influence.
\end{abstract}

Key words: plant communities, soil, ecotone, Latvia, Maritime Lowland.

\section{INTRODUCTION}

A high rate of decomposition and high total microarthropod abundance are characteristic of older, least disturbed ecosystems (Reynolds et al., 2007). Soil disturbance has a major effect on another critical ecosystem factor - the abundance of litter microarthropods. Peatlands might represent such an undisturbed habitat. Peatlands form in the areas of poor drainage where both mineral soil and lower peat layers are in constant waterlogged condition (Finnamore, 1987). Peatlands are divided into two main types, fens and bogs, which can be characterised by vegetation and $\mathrm{pH}$. An alkaline fen is a peat-covered area fed by mineral-rich waters, in which sedges and brown mosses usually dominate, and $\mathrm{pH}$ is alkaline. This type of fens is called a rich fen, and they are rich in species (Hajek et al., 2006). Fens are an important and unique wetland type. Species of fauna and flora are unique in alkaline fens and many are protected in Europe (Stanova et al., 2008).

A high ground water level is one of the most important aspects that sustains alkaline fens and influences species composition of plants and animals. Calcium levels may be high when mineral bedrock is close to the fen surface or a continuous supply of calcium-rich groundwater is present ( $\mathrm{Ta}$ baka, 1960; Pakalne, 2008). Alkaline fens are semi-aquatic habitats with plant species like Cladium mariscus, Carex dawalliana, C. elata, C. lasiocarpa, Schoenus ferrugineus, Phragmites australis, and mosses Calliergonella cuspidata and Scorpidium scorpidiodes. Saw-Sedge C. mariscus is an aggressive plant and may form monodominant vegetation cover, thus outcompeting other plant species, including Brown Bog Rush Schoenus ferrugineus. We hypothesise that soil invertebrates might between these two plant communities.

Mesostigmata mites have been investigated in peat bogs in Europe (Silvan et al., 2000; Skorupski et al., 2008) and also in some semi-aquatic habitats (Kaluž, 1997; Reynolds et al., 2007). These mites are abundant and a diverse group of microarthropods in the soil, albeit data on them in fens are scarce, and only few investigations have been performed so far (Gwiazdowicz and Gulvik, 2007; Marquardt and Kaczmarek, 2009). Recently also Oribatida mites were investigated in Apšuciems fen (Kagainis and Spungis, 2011).

The Mesostigmata mite fauna has been investigated in Latvia since the $19^{\text {th }}$ century (Grube, 1859) and faunistic and ecological data recently have been summarised (Salmane, 2001; 2011; Salmane and Brumelis, 2010). However, no investigations of alkaline fen inhabiting species have been performed up to now. The aim of the current investigation was to describe Mesostigmata mite assemblages in Apšuciems alkaline fen and determine effects of vegetation and soil factors.

\section{MATERIAL AND METHODS}

Apšuciems fen is situated in the Engure municipality, Latvia (central coordinates $57^{\circ} 05^{\prime} 29^{\prime \prime}, 23^{\circ} 31^{\prime} 69^{\prime \prime}$ ) (Fig. 1). 


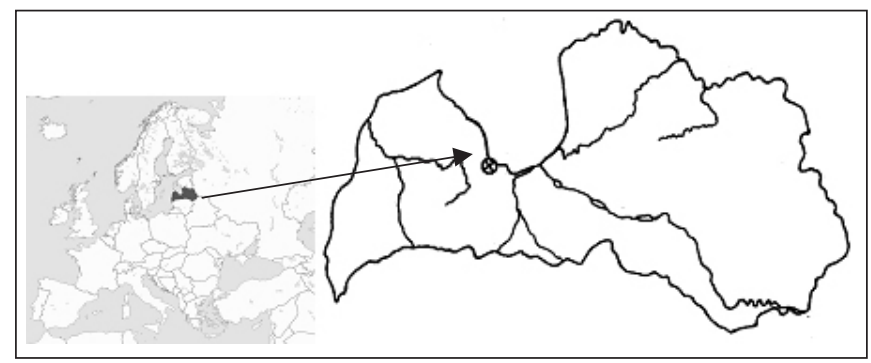

Fig. 1. Location $(\otimes)$ of Apšuciems fen in Latvia.

This fen represents two habitats of EU importance: Alkaline fens with Cladium mariscus and species of the Caricion davallianae (Code 7210) and Alkaline fens (Code 7230) (Anonymous, 2007). The fen is a Natura 2000 site.

The investigation was conducted in Apšuciems fen on May 20 and on September 13, 2009. A 60-m transect with 30 sample plots was chosen crossing two plant communities. Area of sample plots was $1 \mathrm{~m}^{2}$; distance between plots was two meters. Half of plots (P1-P15) occurred in an area dominated by Schoenus ferrugineus and the other half (P16-P30) in an area dominated by Cladium mariscus.

Soil samples were collected in the centre of every sample plot using a soil borer (sample area $0.01 \mathrm{~m}^{2}$ ) at 5-cm depth. Mites were extracted on modified Berlese funnels (Dunger et al., 1997) during a seven-day period and $25 \mathrm{~W}$ light bulbs were used. Specimens were sorted and mounted in modified Berlese media (Upton, 1993). Species were identified using keys (Bregetova, 1977; Karg, 1993; Mašan, 2001; Kaluž and Fenda, 2005). The material is deposited in the Institute of Biology, University of Latvia.

The Braun-Blanquet method (Braun-Blanquet, 1964) was used to describe vegetation cover in each sample plot on July, 2009. Cover of plant species was expressed in classes. Soil moisture was evaluated by the presence/absence of free water on the fen's surface. Spring samples were saturated with water, while autumn samples were moderately wet.

The dominance classes of mites were calculated in accordance with the Engelmann (1978) classification. MS Excel was used to visualise results. Gamasina and Uropodina mites were treated separately. Detrended Correspondence Analysis (DCA; PC-ORD 5 programme package) was used to determine vegetation gradients and to characterise mite assemblages and factors influencing them (mite and plant species represented in samples only by one individual were omitted in the analysis). Shannon-Wiener index were determined for mites and plants in sample plots. The numbers of males, females and deutonymphs in every sample were merged.

\section{RESULTS}

Abundance and species diversity of the Mesostigmata mites was significantly higher in autumn samples than in spring (Table 1). Therefore, only autumn samples were used for further statistical analysis. Two Gamasina species, Perga- masus vagabundus and Prozercon kochi, dominated at both sampling times. Females, males and deutonymphs of Pergamasus vagabundus were represented in proportions 22, 11 and $67 \%$ of the population in May and 42, 16 and $42 \%$ in September. In Prozercon kochi, females dominated over males (91.9\% and $71.29 \%$, respectively).

The cover of vascular plants significantly differed between the two groups of sample plots, while the moss cover and $\mathrm{pH}$ were similar (Table 2). The vascular plant species Myrica gale, Schoenus ferrugineus, Cladium mariscus, Molinia caerulea, Carex panicea, Potentilla erecta, Parnassia palustris, Succisa pratensis and Scirpus tabernaemontani and mosses Campylium stellatum, Calliergonella cuspidata and Fissidens adianthoides had the largest cover.

DCA ordination results of the vegetation data are shown in Fig. 2. The plots were divided into two definite groups. Axis 1 clearly showed changes in the vegetation cover: from plots dominating by Cladium mariscus (to the right) to plots dominating by Schoenus ferrugineus (to the left). Axis 2 could not be explained.

Distribution of Gamasina mites along the transect was similar in both sampling dates (Fig. 3) showing a preference to the ecotone - border between two plant associations. Schoenus ferrugineus was dominant in the sample plots P1-P15, while Cladium mariscus - in the sample plots P16-P30.

Uropodina were analysed separately. These mites also showed preference to the ecotone (Fig. 4). Schoenus ferrugineus was dominant in the sample plots P1-P15, while Cladium mariscus - in the sample plots P16-P30.

DCA ordination of Mesostigmata data showed that plots did not cluster in the same groups as vegetation data (Fig. 5).

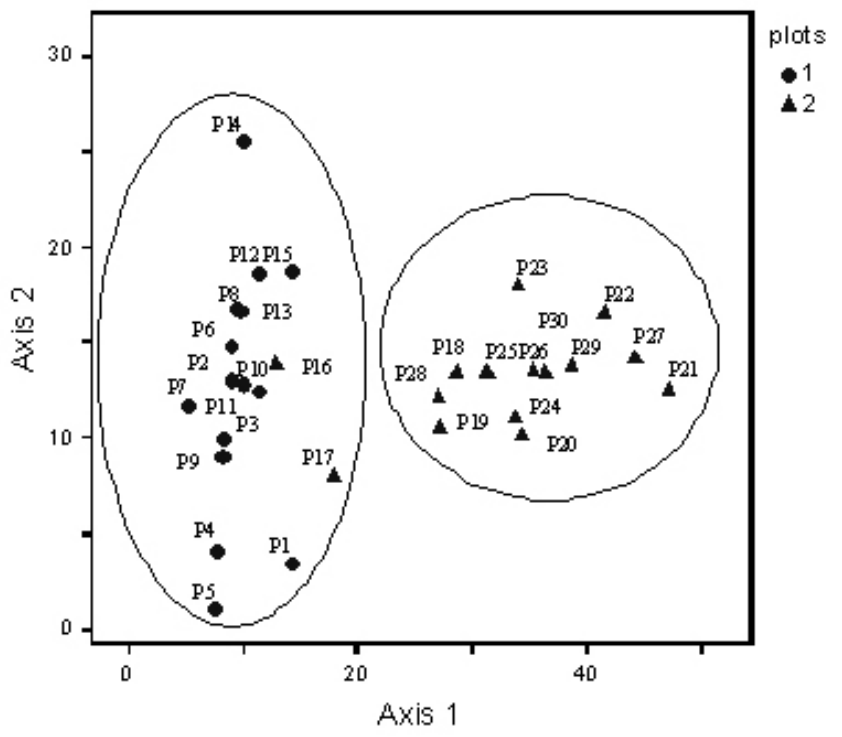

Fig. 2. DCA ordination based on vegetation data from the Apšuciems fen, July, 2009. Axis 1 eigenvalue is 0.35 , Axis $2-0.09$. Dots represent sample plots dominated by Schoenus ferrugineus, triangles - plots dominated by Cladium mariscus. 
MESOSTIGMATA SPECIES LIST, ABUNDANCE AND DOMINATION OF GAMASINA SPECIES IN APŠUCIEMS FEN IN 2009

\begin{tabular}{|c|c|c|c|c|c|}
\hline \multirow[t]{2}{*}{ Taxon } & \multirow[t]{2}{*}{ Abbreviations } & \multicolumn{2}{|c|}{ Date and abundance } & \multicolumn{2}{|c|}{ Domination of Gamasina (\%) } \\
\hline & & May 20 & September 13 & May 20 & September 13 \\
\hline Veigaia nemorensis (C.L.Koch, 1839) & veinem & 5 & 12 & 5.10 & 2.19 \\
\hline V. kochi (Trägårdh, 1901) & veikoc & 9 & 4 & 9.18 & 0.73 \\
\hline V. cervus (Kramer, 1876) & veicer & 1 & 23 & 1.02 & 4.20 \\
\hline Pergamasus vagabundus Karg, 1968 & pervag & 21 & 113 & 21.43 & 20.66 \\
\hline P. brevicornis Berlese, 1903 & perbre & 0 & 11 & 0 & 2.01 \\
\hline P. lapponicus Trägardh, 1910 & perlap & 4 & 34 & 4.08 & 6.22 \\
\hline P holzmannae Micherdzinski, 1969 & perhol & 0 & 1 & 0 & 0.18 \\
\hline P. misellus Berlese, 1904 & permis & 0 & 6 & 0 & 1.10 \\
\hline Holoparasitus excipuliger (Berlese, 1905) & holexc & 7 & 15 & 7.14 & 2.74 \\
\hline Neojordensia sinuata Athias-Henriot, 1973 & neosin & 0 & 2 & 0 & 0.37 \\
\hline C. serratus (Halbert, 1915) & cheser & 0 & 28 & 0 & 5.12 \\
\hline C. dungeri Karg, 1971 & chedun & 3 & 30 & 3.06 & 5.48 \\
\hline C. bryophilus Karg, 1969 & chebry & 0 & 23 & 0 & 4.20 \\
\hline Leioseius minusculus (Berlese, 1905) & leimin & 0 & 1 & 0 & 0.18 \\
\hline L. bicolour (Berlese, 1918) & leibic & 0 & 1 & 0 & 0.18 \\
\hline Antennoseius borrusicus Sellnick, 1945 & antbor & 0 & 1 & 0 & 0.18 \\
\hline Ololaelaps placentula (Berlese, 1887) & olopla & 3 & 6 & 3.06 & 1.10 \\
\hline Hypoaspis vacua (Michael, 1891) & hypvac & 0 & 1 & 0 & 0.18 \\
\hline H. nolli Karg, 1962 & hypnol & 0 & 1 & 0 & 0.18 \\
\hline Geholaspis longispinosus (Krämer, 1876) & gehlon & 0 & 3 & 0 & 0.55 \\
\hline Stylochirus physogastris Karg, 1971 & styphy & 0 & 1 & 0 & 0.18 \\
\hline Prozercon kochi Sellnick, 1943 & prokoc & 31 & 178 & 31.63 & 32.54 \\
\hline Number of species & & 15 & 28 & & \\
\hline Number of individuals & & 157 & 641 & & \\
\hline Population density (ind./m²) & & 520 & 2140 & & \\
\hline
\end{tabular}
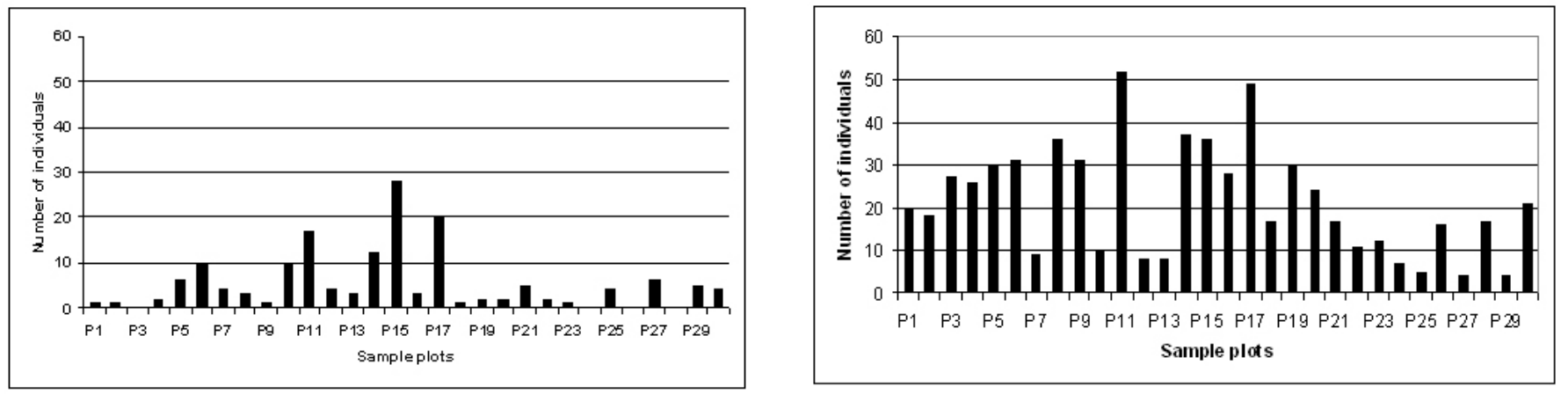

Fig. 3. A distribution of Gamasina mites along the transect crossing two plant associations in the Apšuciems fen on May 20 and on September 13 , 2009. Schoenus ferrugineus was dominant in the sample plots P1-P15, while Cladium mariscus in the sample plots P16-P30.

Sample plots formed two groups. The right group included almost all plots dominated by Cladium mariscus, and the left group by plots mainly dominated by Schoenus ferrugineus. Thus, Axis 1 can be explained as changes from plots dominating by Schoenus ferrugineus (to the left) to the plots dominating by Cladium mariscus (to the right). Observations showed that Cladium mariscus prefers more damp soil conditions with open water present, compared to
Schoenus ferrugineus habitat. Axis 2 could not be explained, but Scirpus tabernaemontana was somewhat associated with this axis.

The Gamasina species also did not form so clear clusters grouping the ordination as for vegetation (Fig. 6). The distribution of two dominant species Pergamasus vagabundus and Prozercon kochii was opposite: the first species was in- 
Table 2

MEAN DOMINANCE CLASSES (ACCORDING TO BRAUNBLANQUET) OF PLANT SPECIES AND MEAN PH IN TWO GROUPS OF SAMPLE PLOTS IN THE APŠUCIEMS FEN IN 2009

\begin{tabular}{|c|c|c|c|}
\hline \multirow[t]{2}{*}{ Plant species } & \multirow[t]{2}{*}{ Abbreviations } & \multicolumn{2}{|c|}{ Groups of sample plots } \\
\hline & & $\mathrm{P} 1-\mathrm{P} 15$ & P16-P30 \\
\hline \multicolumn{4}{|l|}{ Vascular plants } \\
\hline Schoenus ferrugineus & SchFer & 2.47 & 0.67 \\
\hline Carex panicea & CarPan & 1.80 & 0.87 \\
\hline Potentilla erecta & PotEre & 1.67 & 0.33 \\
\hline Molinia caerulea & MoCae & 1.80 & 0.87 \\
\hline Succisa pratensis & SucPra & 1.00 & 0.42 \\
\hline Parnassia palustris & ParPal & 0.87 & 0.53 \\
\hline Sesleria caerulea & SesCae & 0.40 & 0.07 \\
\hline Carex elata & CarEla & 0.40 & 0.13 \\
\hline Scirpus tabernaemontana & SciTab & 0.73 & 0.00 \\
\hline Carex hostiana & CarHos & 0.27 & 0.00 \\
\hline Primula farinosa & PriFar & 0.53 & 0.00 \\
\hline Cladium mariscus & ClaMar & 0.00 & 2.93 \\
\hline Peucedanum palustre & PeuPal & 0.00 & 0.07 \\
\hline \multicolumn{4}{|l|}{ Mosses } \\
\hline Drepanocladus revolvens & DreRev & 2.60 & 1.80 \\
\hline Campylium stellatum & CamSte & 1.60 & 1.87 \\
\hline Calliergonella cuspidata & CalCus & 0.07 & 0.14 \\
\hline Fissidens adianthoides & FisAdi & 0.13 & 0.07 \\
\hline Campylium spp. & CamSpe & 0.00 & 0.07 \\
\hline Pohlia nutans & PohNut & 0.00 & 0.07 \\
\hline Mean pH & & 6.67 & 6.67 \\
\hline
\end{tabular}

Schoenus ferrugineus was dominant in sample plots P1-P15, while Cladium mariscus — in sample plots P16-P30
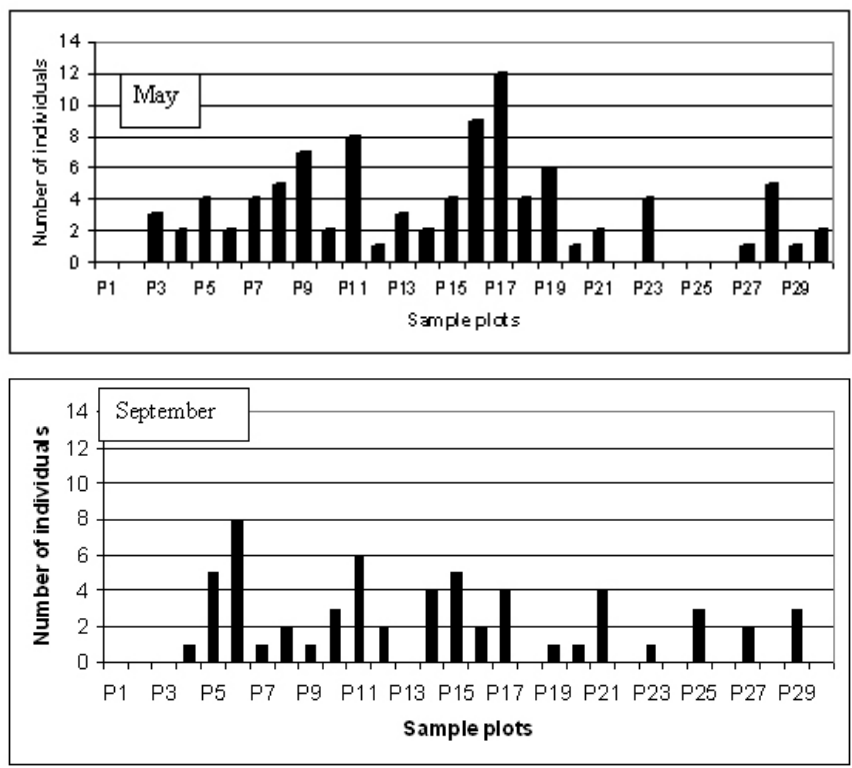

Fig. 4. A distribution of Uropodina mites on the transect crossing two plant associations in the Apšuciems fen on May 20 and on September 13, 2009. Schoenus ferrugineus was dominant in the sample plots P1-P15, while Cladium mariscus - in the sample plots P16-P30.

significantly positively correlated with Axis $1(\mathrm{r}=0.231$, $p>0.05, \mathrm{n}=30$ ) while the second species - significantly

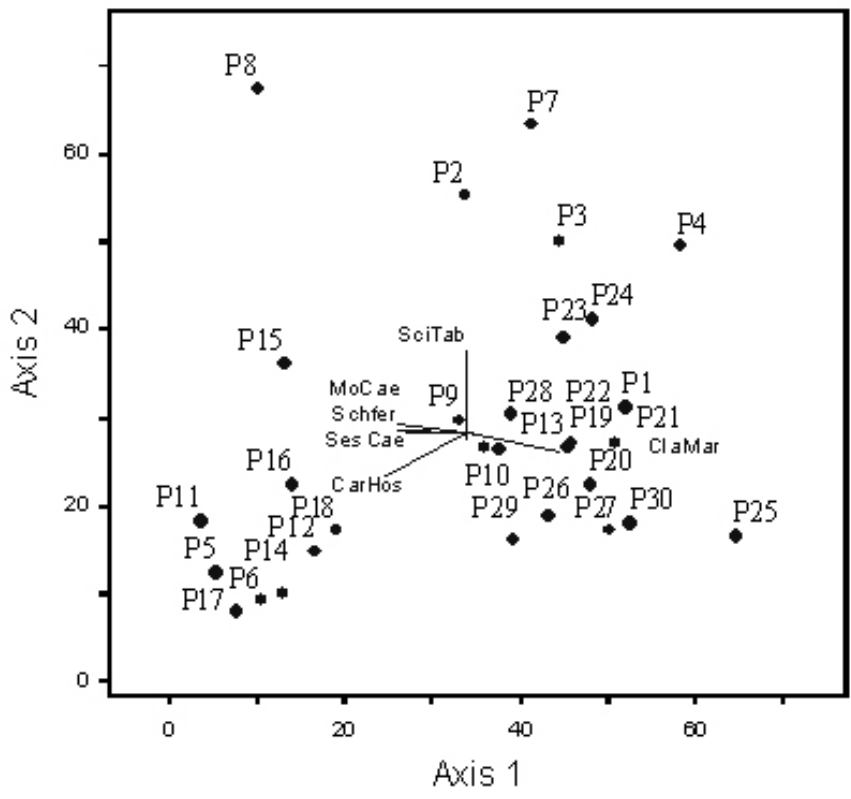

Fig. 5. DCA ordination of sample plots based on Gamasina abundance. Vectors show relation to vegetation factors in the Apšuciems fen in September 13, 2009. Axis 1 eigenvalue is 0.556 , Axis $2-0.294$. For abbreviations of plant species see Table 2 .

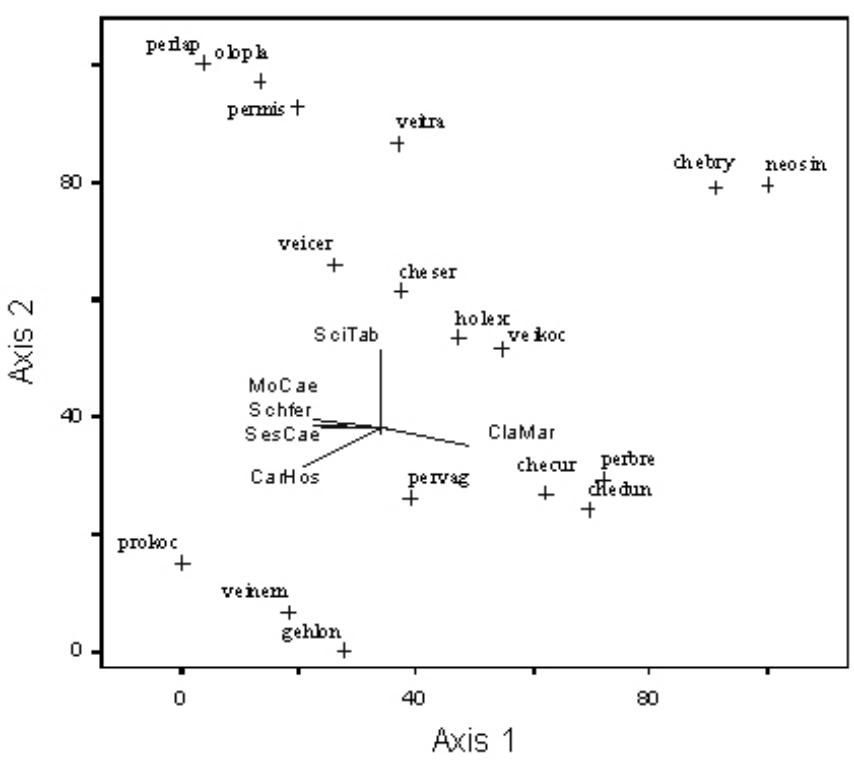

Fig. 6. DCA ordination of Gamasina species based on abundance. Vectors show relation to vegetation factors in the Apšuciems fen on September 13, 2009. Axis 1 eigenvalue is 0.556 , Axis $2-0.294$. For abbreviations of mite species see Table 1, for abbreviations of plant species see Table 2.

negatively $(\mathrm{r}=-0.817, p<0.01, \mathrm{n}=30)$, thus showing preference to plots with Schoenus ferrugineus dominance.

Plant species diversity was not related to mite species diversity; the Spearman correlation between the Shannon-Wiener index of mites and plants in the samples was insignificant $(\mathrm{r}=0.103, p>0.05, \mathrm{n}=30)$.

\section{DISCUSSION}

Obviously, it was not expected to find high Mesostigmata mite diversity in the alkaline fen, which irregularly floods 
with ground and precipitation water. Twenty-four Gamasina species of eight families and one Uropodina species Uroobovella minima and three undetermined Uropodina species were recorded in the Apšuciems fen. This is the first investigation of Mesostigmata in the alkaline fens in Latvia.

The number of species more or less corresponds to those observed in similar habitats in Finland (Huhta et al., 2010): 32 species in an open bog and 26 species in wetland habitats. One Uropodina species Uroobovella pulcehella (inhabiting a poor fen was recorded in Norway (Gwiazdowicz and Gulvik, 2007). Uropodina mites were surveyed in total, with the exception of $U$. minima in the current research. Twenty-nine Mesostigmata species were recorded in low and raised bogs in Lithuania (Eitmanaviciute, 2003), of seven species were found in the Apšuciems alkaline fen in Latvia: Veigaia transisalae, V. cervus, Pergamasus brevicornis, P. misellus, Cheiroseius serratus, Ololaelaps placentula and Prozercon kochi. The species Hypoaspis vacua was recorded in peatbogs in Poland (Bloszyk and Halliday, 1996).

Mesostigmata fauna has been investigated in eight raised bogs of Latvia, where 29 species of nine families were found (Lapina, 1988).

Four of six species of the family Veigaiaidae registered in Latvia so far (Salmane, 2011) were recorded in the Apšuciems fen (Table 1). Mites of the genus Veigaia (Veigaiaidae) are known to inhabit the Holarctic region (Blaszak et al., 2006). V. nemorensis is the most widely distributed in various habitats among species of the genus (Bregetova, 1977; Karg, 1993; Blaszak et al., 2006). It is also the most abundant and ubiquitous species among soil inhabiting Mesostigmata mites in Latvia (Salmane, 2001; 2011). V. nemorensis was found in relatively low density in the Apšuciems alkaline fen (Table 1). It was recorded as a subdominant in raised bogs of Latvia (Lapina, 1988). $V$. transisalae prefers wet to moist habitats in Europe (Bregetova, 1977; Karg, 1993; Blaszak et al., 2006) and previously was recorded in Latvia in bogs and other wet habitats near lakes and rivers (Salmane, unpublished data). $V$. kochi is distributed in the Palaearctic region and has been recorded in a wide range of habitats (Bregetova, 1977; Karg, 1993; Blaszak et al., 2006). This is a common, but not abundant species in Latvia, and has been found in forests, grasslands, dunes and bogs (Lapina, 1988; Salmane, 2011). In the current investigation it was the only species that was more abundant in spring samples (Table 1). $V$. cervus is a common species through the Holarctic region, preferring wet to moist habitats (Bregetova, 1977; Karg, 1993; Blaszak et al., 2006). It was observed to be a subrecedent species in raised bogs of Latvia (Lapina, 1988). Generally, this species was not numerous in the Apšuciems fen and was more abundant in autumn.

Six species of the family Parasitidae were found in the Apšuciems fen (Table 1). Pergamasus vagabundus was recorded as a second dominant species in the current investigation, while it was described as a subrecedent in raised bogs in Latvia (Lapina, 1988). This species is known from the wide variety of habitats in the Palaearctic region, preferring wet habitats, but also found in dry habitats (Bregetova, 1977; Karg, 1993). P. vagabundus has been recorded in various habitats and is a ubiquitous species in Latvia (Salmane and Brumelis, 2010). The other four Pergamasus species and Holoparasitus excipuliger are inhabitants of various habitats, often preferring wet sites in Europe (Micherdzinski, 1969; Karg, 1993). These species are recedents or subrecedents in raised bogs in Latvia (Lapin,a, 1988).

Neojordensia sinuata of the family Aceosejidae is known from the rhizosphere and mosses in Europe (Karg, 1993; Gwiazdowicz, 2007). Only two specimens were found in our investigation. The species of Aceosejidae, including genus Cheiroseius, were mentioned by Lapina (1988) as rare in raised bogs of Latvia. In the current investigation, four relatively abundant species were recorded (Table 1). Cheiroseius dungeri and Ch. bryophilus are new to the fauna of Latvia (Salmane, 2009). They inhabit soil and wet mosses, and litter in Europe and are considered rare in Slovakia (Karg, 1993; Kalúž and Fenda, 2005; Fenda and Kalúz, 2009). Lapina (1988) did not record the genus Cheiroseius in raised bogs of Latvia.

Population density of Gamasina mites ranged from 520 to $2140 \mathrm{ind} . / \mathrm{m}^{2}$. The mite density depended on soil moisture and season. The fen was wet; open water occurred in spring, while it was relatively dry in the autumn. Due to this, the population density was significantly lower in spring, compared to autumn. Similar observations were made in a study of a peatland drainage area in Finland (Silvan et al., 2000). Changes in the density are related also to the Mesostigmata mite life cycle, as the highest abundance occurs in autumn (Kaluž, 1997; Salmane, 2000; Silvan et al., 2000; Laiho et al., 2001).

The dominant species $P$. kochi has a wide range of distribution with high ecological plasticity (Bregetova, 1977; Mašan and Fenda 2004). It has been recorded from Central Europe, West Russia and Scandinavia. This species is characterised as a hygrophilous euedaphic detritocole occurring in litter, mosses, rotting wood and the plant rhizophere. P. kochi was found in several raised bogs in previous studies in Latvia (Lapina, 1988; Salmane and Brumelis, 2010; Salmane, 2011). It prefers dryer microhabitats dominated by Schoenus ferrugineus, which forms hummocks, thus hypothetically providing dryer environmental conditions in the Apšuciems fen.

An effect of vascular plant cover on distribution and abundance of Mesostigmata mites in Apšuciems fen was not clear. Plant communities dominated by Cladium mariscus or Schoenus ferrugineus formed specific and differing Mesostigmata mite communities. Obviously, in the existing specific soil conditions the presence of open water in Cladium mariscus growth is more important limiting factor for mites than plant species diversity. 
It was expected that mosses might influence mite distribution by providing different microhabitats, but this was not observed. Soil $\mathrm{pH}$ did not have much variability, and therefore, it was not possible to evaluate its effect on the distribution of mites. Soil moisture in the upper layer of soil differed, as became dryer in autumn. Experimental observations (Huhta and Hänninen, 2001) showed that moisture regime did not influence significantly neither species richness nor diversity, while at least Veigaia nemorensis prefered constant moisture. That might be explained by the low abundance of this usually common species. Karg (1993) and Salmane (unpublished data) recorded Pergamasus vagabundus from bogs and wet substrates. This species is ubiquitous and occurs in various habitats, especially in various forests (Lapina, 1988), but also is found in meadows, agricultural soils and other habitats in Europe (Karg, 1993; Salmane, 2011). The species was found also in mosses (Karg, 1993; Gwiazdowicz, 2010; Salmane (unpublished data)). P. vagabundus, in contrast to Prozercon kochi, preferred wetter habitat.

We investigated Mesostigmata only two times per year. Thus, the results of the present research can be regarded as preliminary. In the future, study of distribution of mite assemblages in habitats and particularly microhabitats of fens should be continued.

\section{ACKNOWLEDGEMENTS}

We are grateful to M. Pakalne (University of Latvia) for assistance in plant identification and colleagues A. Karpa and U. Kagainis (Institute of Biology, University of Latvia) for assistance during the fieldwork. The research was performed in the frames of the project of the Latvian Council of Science, "Factors limiting diversity of animals in terrestrial ecosystems - interaction of natural and anthropogenic factors".

\section{REFERENCES}

Anonymous (2007). Interpretation Manual of European Union Habitats. EUR 27. European Commission, DG Environment, Nature and Environment. $142 \mathrm{pp}$.

Blaszak, C., Ehrnsberger, R., Skorupski, M. (2006). European mites of the genus Veigaia Oudemans, 1905 (Acari, Gamasida: Veigaiaidae). Abh. Ber. Naturkundemus. Görlitz, 78 (1), 3-9.

Bloszyk, J., Halliday, B. (1996). Contributions to the knowledge of the acarofauna of Roztocze. IV. Mesostigmata mites (Acarina: Mesostigmata). Fragmenta Faunistica, 39 (1), 1-13.

Braun-Blanquet, J. (1964). Pflanzensoziologie: grundzüge der vegetationskunde. Zweite, umgearbeitete und vermehrte Auflage. Wien: SpringerVerlag. $865 \mathrm{~S}$.

Bregetova, N.-G. (1977). Identification Keys for Soil Inhabiting Mites. Mesostigmata [Брегетова, Н.-Г. Определитель почво-обитающих клещей. Mesostigmata]. Leningrad: Nauka. 717 pp.

Dunger, W., Fiedler, H.-J. (1997). Methoden der Bodenbiologie. Jena: Gustav Fischer Verlag Jena. 539 S.

Eitmanaviciute, I. (2003). Soil Mites of Lithuania. Acari (Catalogue). Vilnius: Vilnius universiteto Ekologijos instituto leidykla. 168 pp.
Engelmann, A.-D. (1978). Zur Dominanzklassifizierung von Bodenarthropoden. Pedobiologia, 18, 378-380.

Fenda, P., Kalúz, S. (2009). Distribution and ecology of the ascid mites in Slovakia (Acari Mesostigmata, Ascidae). In: Tajovsky, K., Schlaghamersky, J., Pižl, V. (eds.). Contributions to Soil Zoology in Central Europe. III. České Budǵjovice: Institute of Soil Biology Academy of Sciences of the Czech Republic, pp. 33-40.

Finnamore, A.-T. (1987). Invertebrate biodiversity in North temperate peatlands. Newsletter of the Biological Survey of Canada (Terrestrial Arthropods), 6 (1), 1-6.

Grube, A.-E. (1859). Verzeichnis der Arachnoiden Liv-, Kur- und Ehstlands. Aus der Archiv fur die Naturkunde Liv-, Kur-und Ehstlands. Dorpat. 72 pp.

Gwiazdowicz, D.-J., Gulvik, M.-E. (2007). The first records of five mite species (Acari. Mesostigmata) in Norway. Norwegian J. Entomol., 54, $117-124$.

Gwiazdowicz, D.-J. 2007. Ascid Mites (Acari, Mesostigmata) from Selected Forest Ecosystems and Microhabitats in Poland. Poznan: Wydawnictwo Akademii Rolniczej im. Augusta Cieszkowskiego. 148 pp.

Gwiazdowicz, D. J. (2010). Mites (Acari, Mesostigmata) of the Tatra National Park. Acta Sci. Pol. Silv. Colend. Ratio. Ind. Lignaria, 9 (1), 5-18.

Hajek, M., Horsak, M., Hajkova, P., Dite, D. (2006). Habitat diversity of central European fens in relation to environmental gradients and an effort to standardise fen terminology in ecological studies. Persp. Plant Ecol., Evol. Syst., 8, 97-114.

Huhta, V., Siira-Pietikäinen, A., Penttinen, R., Räty, M. (2010). Soil fauna of Finland: Acarina. Collembola and Enchytraeidae. Mem. Soc.Fauna. Flora Fenn., 86, 59-82.

Huhta, V., Hänninen, S.-M. (2001). Effects of temperature and moisture fluctuations on an experimental soil microarthropod community. Pedobiologia, 45, 279-286.

Kagainis, U., Spungéis, V. (2011). First data on moss mite (Acari, Oribatida) communities in the alkaline fen Apšuciems, Latvia. Acta Biol. Univ. Daugavpiliensis, 11, 248-258.

Kaluž, S. (1997). Soil mites (Acarina) during hydrological changes in floodplain forest of Danube. Ekológia (Bratislava), 16 (4), 345-357.

Kaluž, S., Fenda, P. (2005). Mites (Acari: Mesostigmata) of the Family Ascidae of Slovakia. Institute of Zoology, Slovak Academy of Sciences, Bratislava. 168 pp.

Karg, W. (1993) Acari (Acarina). Milben Parasitiformes (Anactinochaeta) Cohors Gamasina Leach. Raubmilben. Stuttgart, New York, Jena: Gustav Fischer Verlage. 523 pp.

Laiho, R., Silvan, N., Carcamo, H., Vasander, H. (2001). Effects of water level and nutrients on spatial distribution of soil mesofauna in peatlands drained for forestry in Finland. Appl. Soil Ecol., 16, 1-9.

Lapina, I. М. (1988). Gamasina Mites of Latvia [Лапиня И. М. Гамазовые клещи Латвии]. Riga: Zinatne. 200 pp. (in Russian).

Markkula, I. (1986). Comparison of the communities of the oribatids (Acari: Cryptostigmata) of virgin and forest-ameliorated pine bogs. Ann. Zool. Fenn., 23, 33-38.

Mašan, P. (2001). Mites of the cohort Uropodina (Acarina. Mesostigmata) in Slovakia. Annot. Zool. Bot., 223, 1-321.

Mašan, P., Fenda, P. (2004). Zerconid Mites of Slovakia (Acari, Mesostigmata, Zerconidae). Bratislava: Slovak Academy of Sciences. 238 pp.

Marquardt, T., Kaczmarek, S. (2009). New and rare species of the Gamasida (Acari) in the Polish fauna recorded in „Bagno Stawek” Reserve (Tuchola Forest, northern Poland). Biol. Lett., 46 (1), 37-42.

Micherdzinski, W. (1969). Die familie Parasitidae Oudemans, 1901 (Acarina, Mesostigmata). Panstwowe Wydawnictwo Naukowe, Zaklad Zoologii Systematycznej Polskiej Nauk. 690 pp.

Pakalne, M. (2008). Mire Conservation and Management in Especially Protected Nature Areas in Latvia. Rìga: Latvijas Dabas fonds. 183 pp. 
Reynolds, B.-C., Hamel, J., Isbanioly, J., Klausman, L., Moorhead, K.-K. (2007). From forest to fen: Microarthropod abundance and litter decomposition in a southern Appalachian floodplain/fen complex. Pedobiologia, 51 (4), 273-280.

Salmane, I. (2000). Investigations of the seasonal dynamics of Gamasina mites (Acari, Mesostigmata) in the pine forests of Latvia. Ekológia (Bratislava), 19 (3), 245-252.

Salmane, I. (2001). A check-list of Latvian Gamasina mites (Acari. Mesostigmata) with short notes to their ecology. Latv. Entomol., 38, 27-39.

Salmane, I. (2009). Some new and rare Mesostigmata (Acari, Parasitiformes) in the fauna of Latvia. Latv. Entomol., 47, 71-75.

Salmane, I. (2011). Fauna and distribution of Mesostigmata mites (Acari, Parasitiformes) in habitats of Latvia. Doctoral Thesis. University of Latvia, Rìga, 42 pp.
Salmane, I., Brumelis, G. (2010). Species list and habitat preference of Mesostigmata mites (Acari, Parasitiformes) in Latvia. Acarologia, 50 (3), 373-394.

Silvan, N., Laiho, R., Vasander, H. (2000). Changes in mesofauna abundance in peat soils drained for forestry. Forest Ecol. Manag., 133, $127-133$.

Skorupski, M., Belter, W., Kamcczyc, J., Wierzbicka, A. (2008). Soil mites (Acari. Mesostigmata) of the „Torfowiska Doliny Izery” Reserve in the Sudety Mountains. Soil Org., 80 (2), 261-270.

Stanova, Š., Šeffer, J., Janak, M. (2008). Management of Nature 2000 habitats. 7230 Alkaline fens. Technical Report 2008, 20/24, 1-20.

Tabaka, L. (1960). Kurzemes zāḷu purvu veǵetācija [Vegetation of fens in Kurzeme]. Grām.: Latvijas PSR veǵetācija. 3. sēj. (13.-22. lpp.). Rīga: Latvijas PSR Zinātṇu akadēmijas izdevniecība (in Latvian).

Upton, M.-S. (1993). Aqueous gum-chloral slide mounting media: An historical review. Bull. Entomol. Res., 83, 267-274.

Received 25 September 2014

\section{MESOSTIGMATA ĒRČU (Acari, Parasitiformes) BLĪVUMU UN SABIEDRĪBU STRUKTŪRU IETEKMĒJOŠIE FAKTORI KAL,KAINĀ PURVĀ}

2009. gadā tika pētīta Mesostigmata ērču fauna Piejūras zemienē esošajā Apšuciema kaḷkainajā purvā. Pētījuma veikšanai 15 parauglaukumi tika izvēlēti purva teritorijā, kurā dominē Schoenus ferrugineus, un 15 parauglaukumi — kurā dominē Cladium mariscusi. Augsnes paraugi tika ievākti ar augsnes urbi, un veǵetācija aprakstîta, vadoties pēc Brauna-Blanquet klasifikācijas. Ērces no augsnes paraugiem tika ekstrahētas ar modificētu Berleses eklektoru. Kopumā pētījumā konstatētas vairāk nekā 28 Mesostigmata ērču sugas, no kurām divas ir dominējošās - Prozercon kochi un Pergamasus vagabundus. Mesostigmata ērču vidējais blīvums konstatēts robežās no 520 lìdz $2140 \mathrm{ind} / \mathrm{m}^{2}$. Veiktā pētījuma rezultātā tika secināts, ka ērču vidējais blīvums un sugu izplatība ir saistīta ar vaskulāro augu izplatību, savukārt augsnes pH vērtībai uz šiem rādītājiem nebija būtiskas ietekmes. 